\title{
The occurrence of the microcaddisfly Costatrichia (Trichoptera: Hydroptilidae: Hydroptilinae) in Brazil with description of two new species
}

\author{
Allan Paulo Moreira Santos ${ }^{1,2} \&$ Jorge Luiz Nessimian ${ }^{1}$
}

\author{
${ }^{1}$ Departamento de Zoologia, Instituto de Biologia, Universidade Federal do Rio de Janeiro. Caixa Postal 68044, \\ 21941-971 Rio de Janeiro, RJ, Brazil. \\ 2 Corresponding author. E-mail: a.santos@ufrj.br
}

\begin{abstract}
Costatrichia Mosely, 1937 (Leucotrichiini) is for the first time recorded from Brazil. Two new species are described: Costatrichia nelsonferreirai sp. nov. and C. fluminensis sp. nov. from states of Pará and Rio de Janeiro, respectively. Costatrichia nelsonferreirai sp. nov. is similar to C. bipartita Flint, 1970, but can be distinguished from the latter by a pair of ventrolateral bifurcate processes on the posterior margin of male segment VIII. Costatrichia fluminensis sp. nov. is similar to C. simplex Flint, 1970, but the former can be easily distinguished from the latter by a pair of slender lateral processes on the posterior margin of male segment IX and by a spatulate apical process on phallus.
\end{abstract}

KEY WORDS. Amazon Forest; Atlantic Forest; Costatrichia nelsonferreirai sp. nov.; Costatrichia fluminensis sp. nov.; Leucotrichiini.

Costatrichia Mosely, 1937 is a small and exclusively Neotropical microcaddisfly genus assigned to the Leucotrichiini. The genus was erected for a single species, C. lodora Mosely, 1937, from Mexico. Later, additional species were described: C. panamensis Flint, 1967; C. bipartita Flint, 1970; C. simplex Flint, 1970; C. spinifera Flint, 1970; C. tripartita Flint, 1970; C. venezuelensis Flint, 1981; C. noite Angrisano, 1995; C. flinti Holzenthal \& Harris, 1999; C. carara Holzenthal \& Harris, 1999; C. cressae Holzenthal \& Harris, 1999; and C. zopilote Holzenthal \& Harris, 1999. Immature stages of all species remain unknown (Funt et al. 1999). The genus has been recorded from Mexico to South America (Holzenthal \& HaRris 1999, Flint et al. 1999), but without previous records from Brazil.

Costatrichia, as pointed out by FunT (1970), appears to be related to Leucotrichia Mosely, 1934 and Zumatrichia Mosely, 1937, being particularly similar to the latter in the morphology of the genitalia. FLINT (1970) divided Costatrichia into two species groups: the lodora group and the simplex group. Males of the former have modified antennae and forewings with a reflexed costal cell (basal costal bulla sensu HolzentHAL \& HaRRIs 1999), whereas males of the latter, have unmodified antennae and lack a reflexed costal cell on the forewings. HolzentHAL \& HARRIS (1999) recognized a third group, the tripartita group, including those males with modified antennae and forewings, but with tripartite inferior appendages. As mentioned by Holzenthal \& Harris (1999), these diagnostic features of the species groups also occur in other Leucotrichiini genera and are an indication that Costatrichia may be paraphyletic. MARSHALI (1979) and FurNT (1992) also discussed the fragile generic limits of Leucotrichiini taxa. This problem can only be solved after a reassessment of all genera in the tribe (Holzenthal \& HarRIS 1999).

In this paper, Costatrichia is recorded from Brazil for the first time. Additionally, two new species are described for genus: $C$. nelsonferreirai sp. nov. from the state of Pará and $C$. fluminensis sp. nov. from the state of Rio de Janeiro.

\section{MATERIAL AND METHODS}

Specimens were collected with light traps and preserved in $80 \%$ ethanol. The abdomen was removed and cleared in a solution of heated $10 \% \mathrm{KOH}$. The morphological terminology follows that of Marshall (1979). Pencil sketches were made under an optical microscope (genital structures) or a stereomicroscope (head and wings) and then scanned. Using Adobe Illustrator (v. 13.0, Adobe Systems, Inc.), the digital images were traced to create vector graphics.

Holotypes were deposited in the Coleção Entomológica Professor José Alfredo Pinheiro Dutra, Departamento de Zoologia, Universidade Federal do Rio de Janeiro, Rio de Janeiro (DZRJ). Paratypes were deposited in the same institution, as well as in the Instituto Nacional de Pesquisas da Amazônia, Manaus (INPA) and in the Museu de Zoologia, Universidade de São Paulo, São Paulo (MZSP), as indicated in species descriptions.

\section{TAXONOMY}

\section{Costatrichia Mosely, 1937}

Costatrichia Mosely, 1937: 166 [type species: C. lodora Mosely, 1937, original designation]; Flint, 1970: 11 [revision]; Holzenthal \& Harris, 1999 [revision]. 


\section{Costatrichia nelsonferreirai sp. nov.}

Figs 1-8

Diagnosis. This new species is very similar to C. bipartita, considering the sclerotized subgenital plate (Fig. 6), the mesally fused inferior appendages (Fig. 4), and the general aspect of the phallus, particularly the apical sclerite (Fig. 7). However, C. nelsonferreirai sp. nov. is easily distinguished by the pair of ventrolateral bifurcate processes on the posterior margin of segment VIII (Figs 4 and 6), by the inferior appendages elongate, spatulate, with apex expanded laterally (Fig. 4), and the phallus with the apical sclerite bifurcate, forceps-like (Fig. 7). Although the new species shares the bilobed aspect of segment $\mathrm{X}$ (Fig. 6) with C. noite, other features are very distinctive.

Description. Holotype male. Length (from tip of head to wings apex) $2.4 \mathrm{~mm}$. General color dark brown, in ethanol. Head strongly convex; frontal region with pale brown setae; antennae 20-articulated, scape elongate, pedicel short, flagellomeres I-IV short, broad, and depressed (Fig. 1); three ocelli; maxillary palpi 5-articulated, labial palpi 3-articulated. Forewings with short costal bulla and covered by long brown setae, veins reaching margin (Fig. 2); hind wings with fringes of very long dark brown setae, veins reaching margin (Fig. 3). Abdominal sternum VII with slender process on mesal area, which has short apical spines (Fig. 4). Genitalia: segment VIII, in ventral view, with pair of lateral bifurcate processes on posterior margin and bearing short setae on mesal area (Fig. 4); in lateral view, nar- rowing posteriorly. Segment IX reduced ventrally (Fig. 4); in dorsal view, with small posterolateral lobes bearing long setae (Fig. 5). Segment X membranous and bilobed, ventralmost lobe broader than dorsalmost one (Figs 5 and 6); fused to segment IX anteriorly. Inferior appendages fused mesally, forming a lobe in ventral view, posterior margin spatulate with very short mesal incision and bearing short spine-like setae (Fig. 4). Subgenital plate sclerotized, slightly downturned (Fig. 6). Phallus with basal tubular portion and midlength complex, which bears basal loop and sclerotized dorsal window (Figs 7 and 8); with apical bifurcate sclerite (Fig. 7). Variation: length 2.2-2.4 mm ( $\mathrm{n}=8)$. General color, in ethanol, from brown to dark brown.

Female. Unknown.

Taxonomic summary. Holotype male. Brazil, Pará: Canaã dos Carajás (Floresta Nacional - FLONA - de Carajás, lagoa Redonda, 06²1'20.7”S, 50²3'26.7”W, 705 m), III.2006, N. Ferreira Jr leg., light trap (DZRJ).

Paratypes. Same data as holotype, 2 males (DZRJ); Pará: Parauapebas (FLONA de Carajás, lago N5 Sul, 0605'50.1"S, $\left.50^{\circ} 07^{\prime} 50.1^{\prime \prime} \mathrm{W}, 667 \mathrm{~m}\right)$, III.2005, N. Ferreira Jr leg., light trap, 1 male (MZSP); (FLONA de Carajás, lago N4D, 06 $05^{\prime} 43.0^{\prime \prime} \mathrm{S}$, $\left.50^{\circ} 11^{\prime} 29.6^{\prime \prime} \mathrm{W}, 659 \mathrm{~m}\right), 27 . I I I .2009$, A.P.M. Santos \& N. Ferreira Jr leg., light trap, 2 males (DZRJ); (Área de Proteção Ambiental - APA - do Igarapé Gelado, lago Pêra), 14.III.2009, Laboratório de Limnologia UFRJ leg., light trap, 1 male (MZSP); (APA do Igarapé Gelado, igarapé Geladinho), 14.III.2009, Laboratório de Limnologia UFRJ leg., light trap, 1 male (INPA).

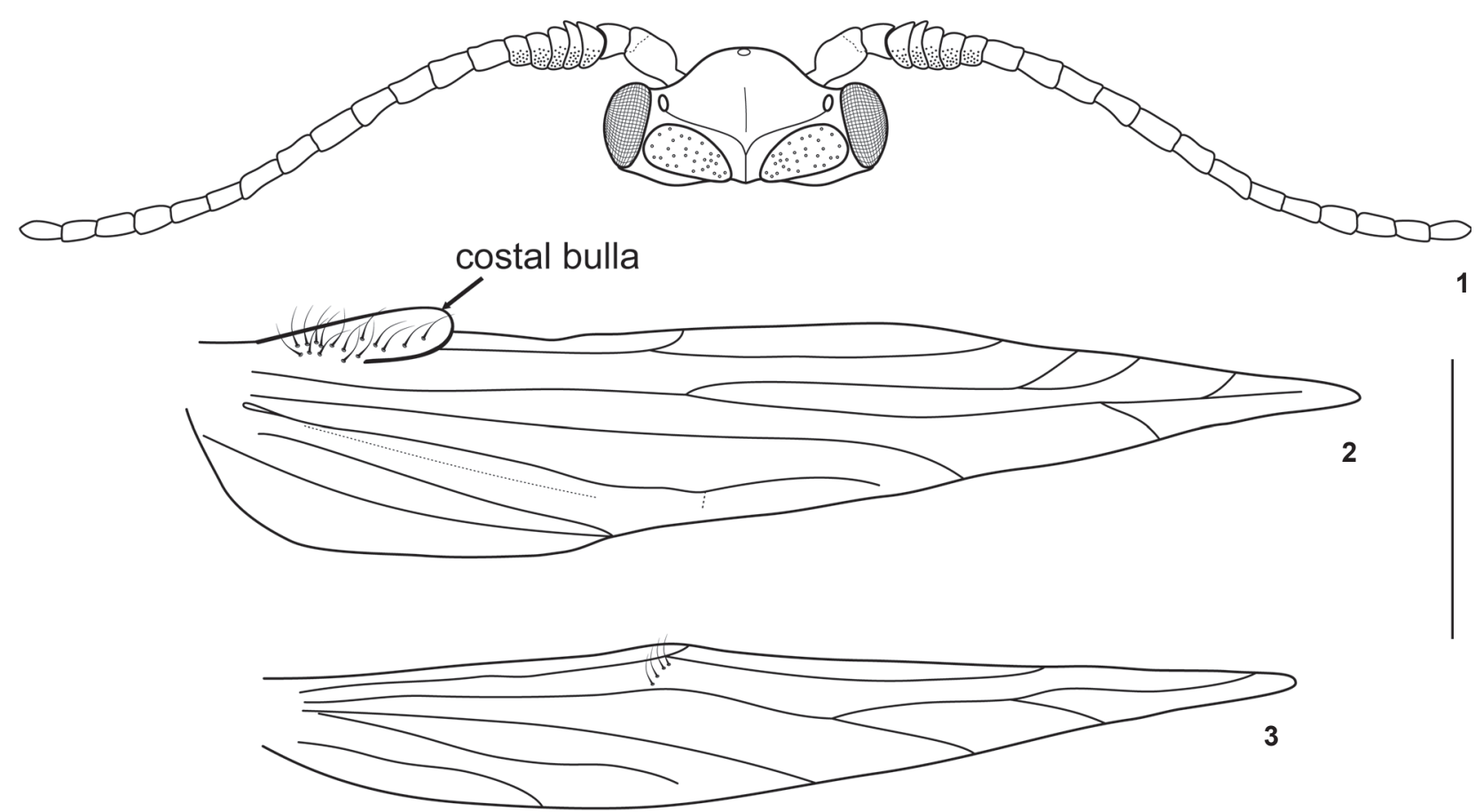

Figures 1-3. Costatrichia nelsonferreirai sp. nov., male: (1) head, dorsal view; (2) forewing; (3) hind wing. Scale bar $=0.5 \mathrm{~mm}$.

ZOOLOGIA 27 (5): 837-843, October, 2010 

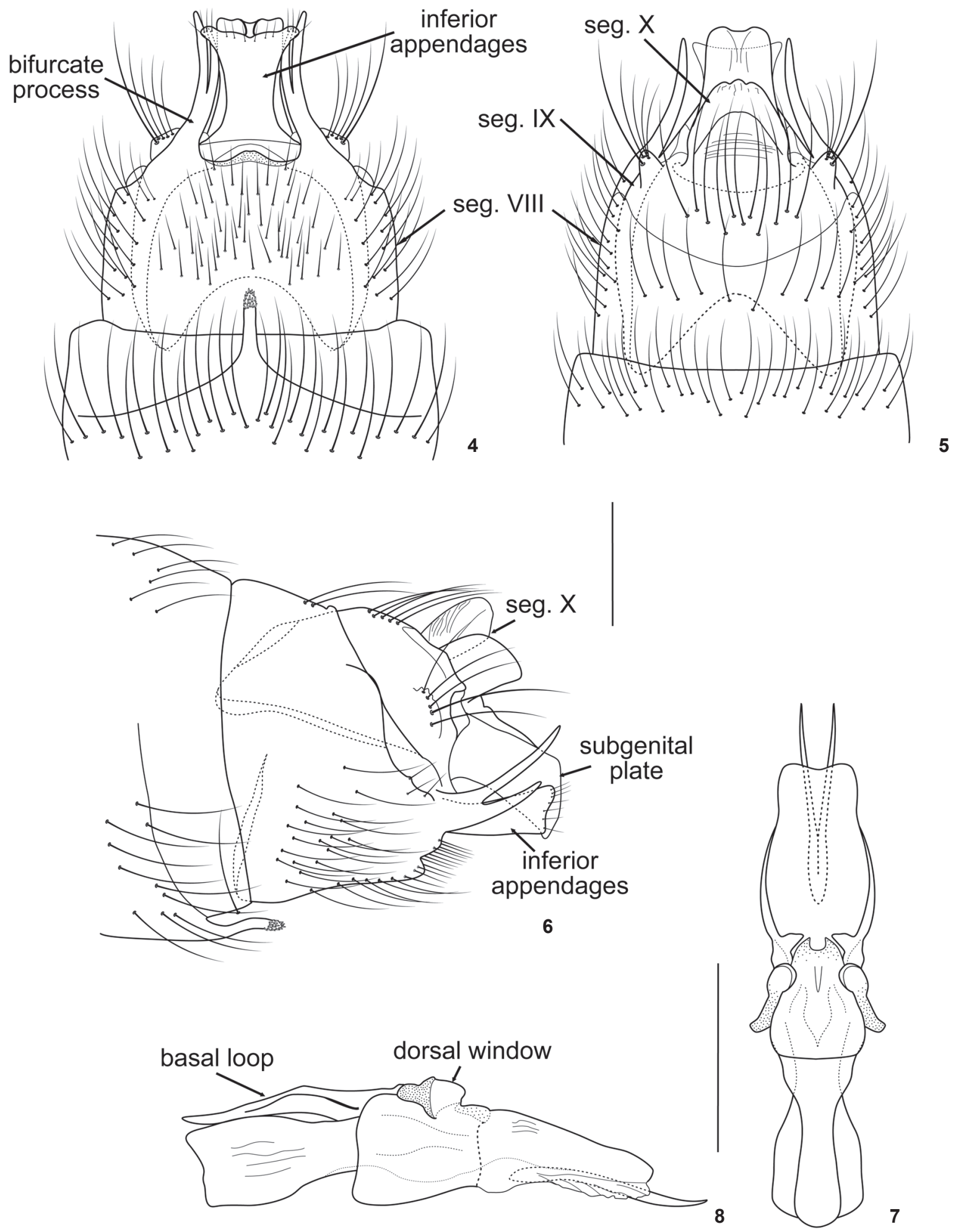

Figures 4-8. Costatrichia nelsonferreirai sp. nov., male genitalia: (4) ventral view; (5) dorsal view; (6) lateral view; (7) phallus, dorsal view; (8) phallus, lateral view. Scale bar $=0.1 \mathrm{~mm}$. 
Etymology. This species is named after Nelson Ferreira Junior, Brazilian entomologist and collector of the types.

Remarks. Specimens of $C$. nelsonferreirai sp. nov. were collected in the Amazon Forest in the state of Pará. Although Costatrichia species occur in other Amazonian countries $(C$. cressae and C. venezuelensis in Venezuela and C. noite in Peru), this new species represents the first record of the genus from Northern Brazil. This new species has the distinctive features of Costatrichia: antennae with basal flagellomeres modified (Fig. 1) and costal bulla on the forewing (Fig. 2). Although some similarity is found between the new species and C. bipartita, the former can be easily recognized, particularly by the ventrolateral bifurcate processes on the posterior margin of segment VIII (Figs 4 and 6).

\section{Costatrichia fluminensis sp. nov.}

Figs $9-19$

Diagnosis. This new species belongs to the simplex group, which includes C. simplex, C. spinifera, and C. zopilote. These species share the simple antenna (Fig. 9) and the absence of costal bulla on the forewing (Fig. 10). Males of C. fluminensis sp. nov. have two short mesal processes on the abdominal sternum VII (Figs 12 and 14), as in C. simplex. Nevertheless, the new species can be easily recognized by the pair of long slen- der processes laterally of the posterior margin of segment IX (Fig. 14), segment X somewhat quadrangular in dorsal view (Fig. 13), and phallus without basal loop and with apical spatulate process in dorsal view (Fig. 15).

Description. Holotype male. Length $3.0 \mathrm{~mm}$. General color brown, in ethanol. Head short; frontal region densely covered by stout jet black setae; setal wart swollen; antennae 19-articulated, scape elongate, pedicel short, flagellomeres terete, flagellomere I elongate (Fig. 9); three ocelli; maxillary palpi 5-articulated, labial palpi 3-articulated. Forewings without costal bulla and covered by long dark brown setae, with some pale yellow setae at midlength, veins reaching margin (Fig. 10); hind wings with fringes of very long dark brown setae, veins reaching margin (Fig. 11). Abdominal sternum VII with two short mesal pointed processes (Fig. 12). Genitalia: segment VIII, in ventral view, with posterior margin slightly emarginated, bearing short setae on mesal area and long setae posterolaterally (Fig. 12); in dorsal view, short and with mesal row of long setae (Fig. 13); in lateral view, projected ventrally and narrowing posteriorly (Fig. 14). Segment IX reduced ventrally (Fig. 12); in dorsal view, with mesal row of long setae (Fig. 13); in lateral view, with pair of long slender downturned processes, ending into apical dark spine (Fig. 14). Segment X membranous, somewhat quadrangular in dorsal view (Fig. 13) and narrow in lateral view (Fig. 14); fused to segment IX anteriorly. Inferior ap-
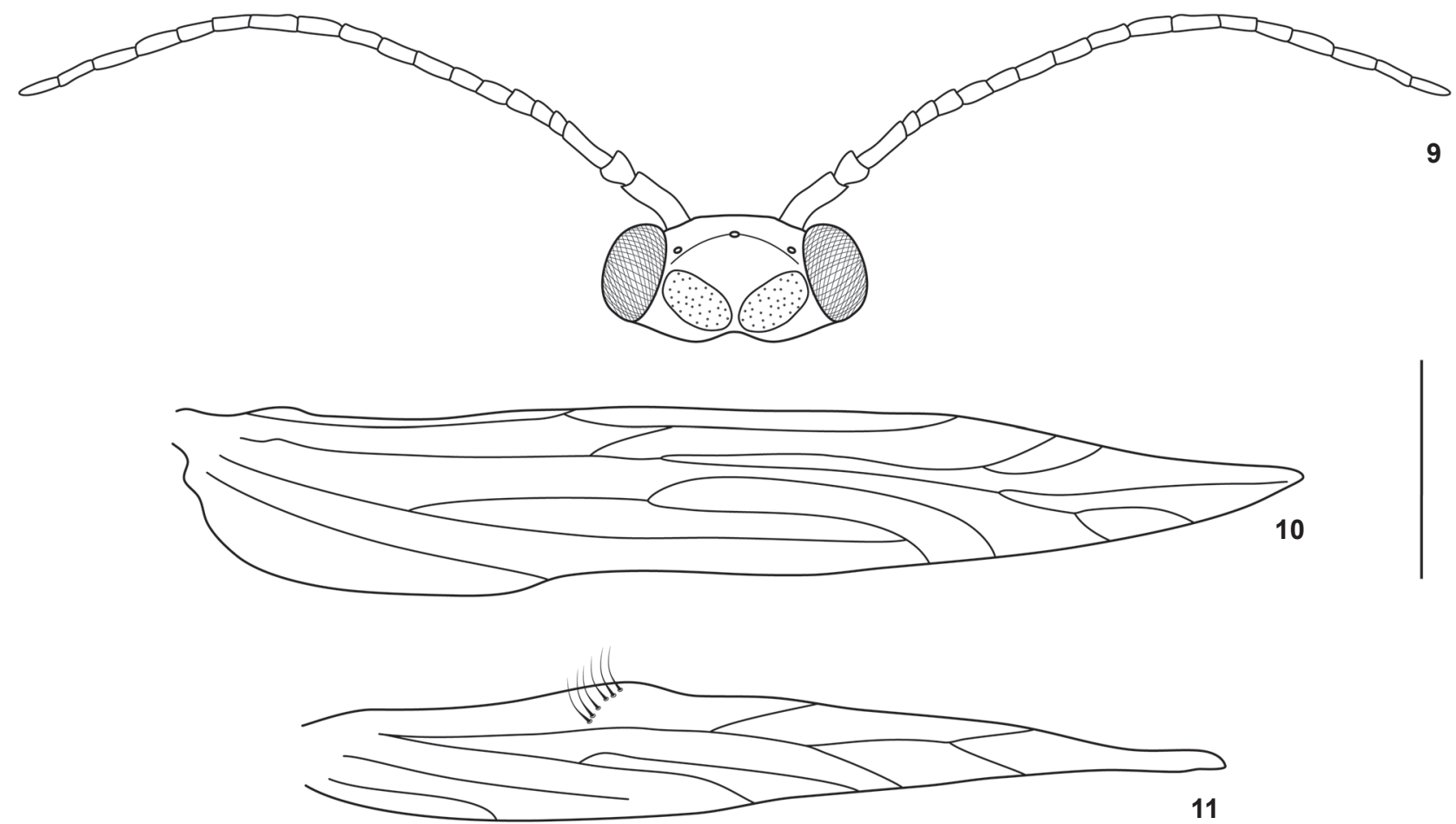

Figures 9-11. Costatrichia fluminensis sp. nov., male: (9) head, dorsal view; (10) forewing; (11) hind wing. Scale bar $=0.5 \mathrm{~mm}$.

ZOOLOGIA 27 (5): 837-843, October, 2010 

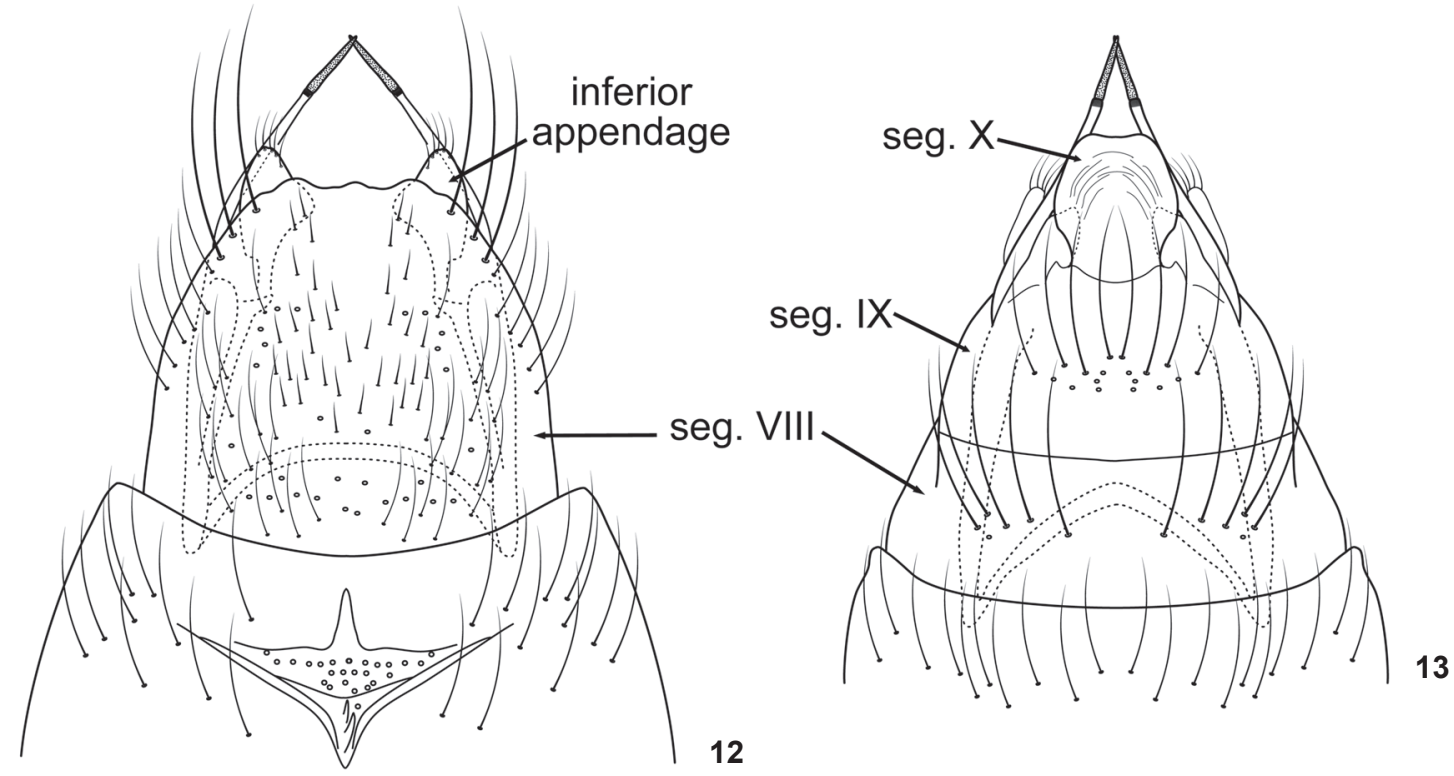

12
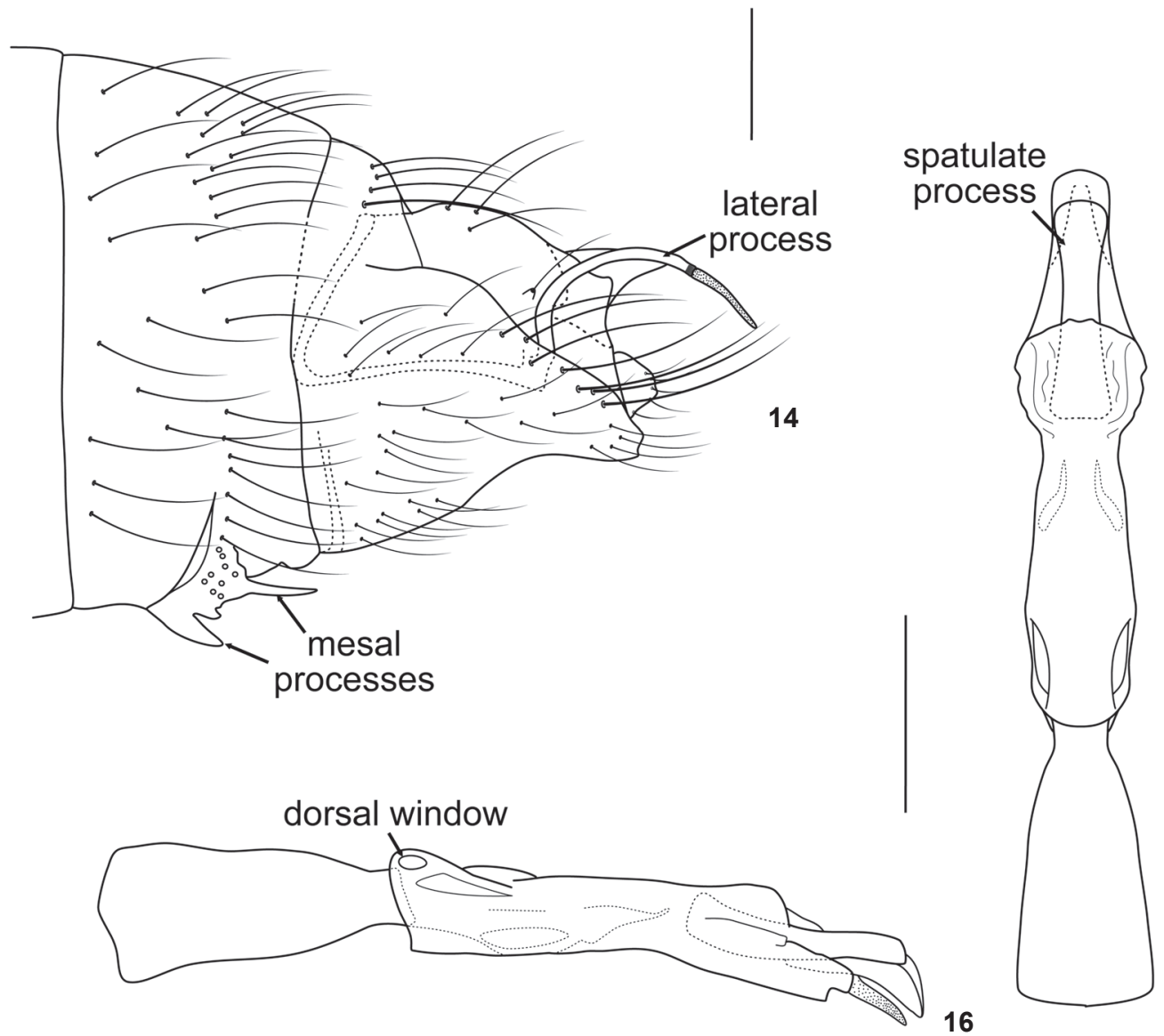

15

Figures 12-16. Costatrichia fluminensis sp. nov., male genitalia: (12) ventral view; (13) dorsal view; (14) lateral view; (15) phallus, dorsal view; (16) phallus, lateral view. Scale bar $=0.1 \mathrm{~mm}$. 


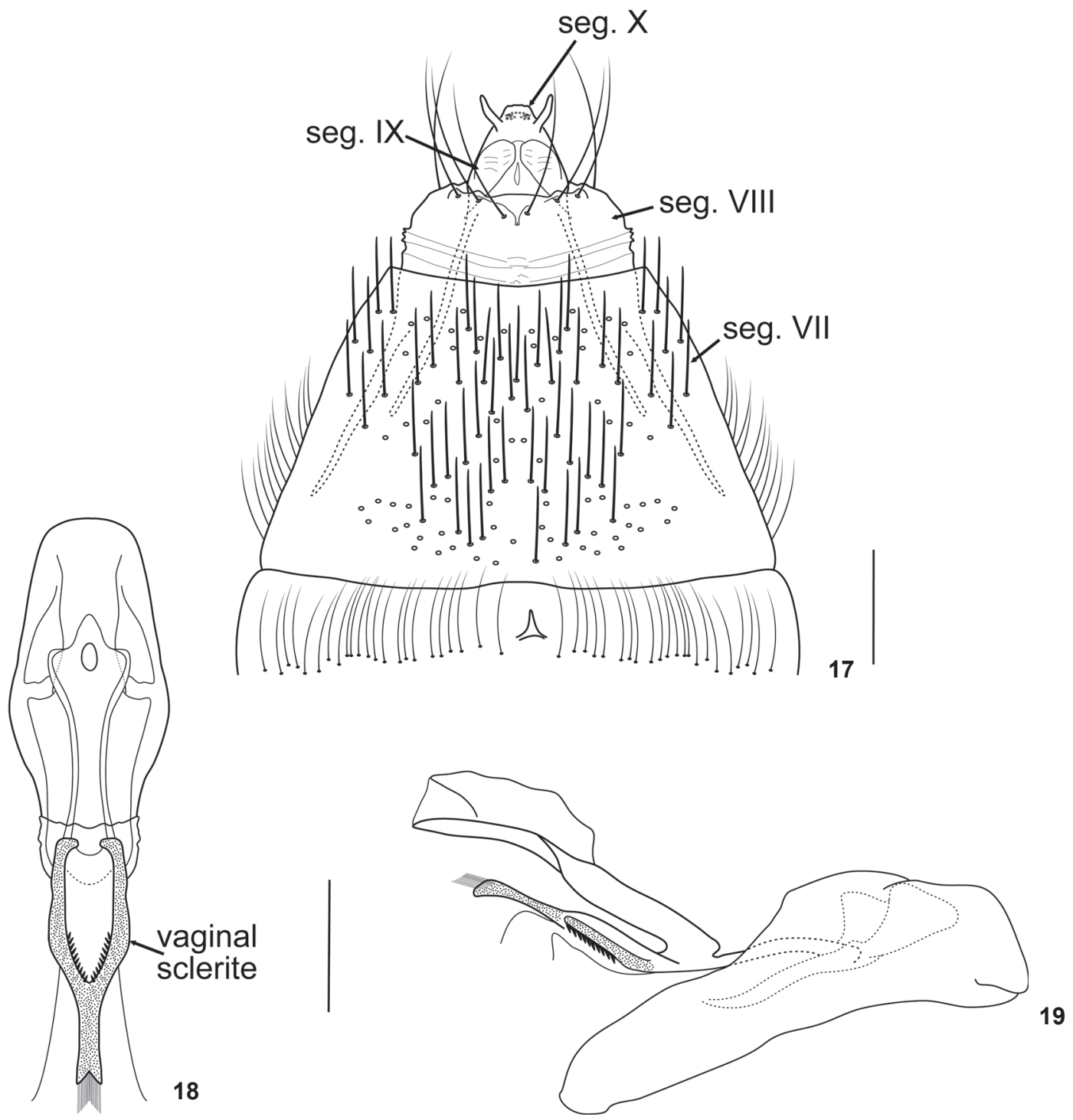

Figures 17-19. Costatrichia fluminensis sp. nov., female genitalia: (17) ventral view; (18) bursa copulatrix, ventral view; (19) bursa copulatrix, lateral view. Scale bar $=0.1 \mathrm{~mm}$.

pendages short, subtriangular in ventral view, bearing short setae (Figs 12 and 14). Subgenital plate absent. Phallus with basal tubular portion, basal loop absent and dorsal window present (Figs 15 and 16); apically, with dorsal spatulate process (Fig. 15) and ventral spine-like process (Fig. 16). Variation: length 2.8-3.0 mm $(\mathrm{n}=6)$. General color, in ethanol, from brown to dark brown.

Female. Length 3.0-3.1 $\mathrm{mm}(\mathrm{n}=2)$. Coloration and wings as in male. Head and antennae simple. Segment VI with short ventral process (Fig. 17). Genitalia: segment VII annular, in ventral view, with straight setae (Fig. 17). Segment VIII short, with posterior margin emarginated and with row of long setae, with lateral apodemes extending to segment VII (Fig. 17). Segment IX short, with two lobes ventrally, with lateral apodemes extending to middle of segment VII (Fig. 17). Segment X truncate posteriorly and with pair of subapical papillae (Fig. 17). Bursa copulatrix with posterior lobe approximately oval in ventral view (Fig. 18) and connected with vaginal sclerite by pair of thin tubes (Fig. 19). Vaginal sclerite lyre-like; in lateral view, with serrate teeth ventrally and with setal brush anteriorly (Fig. 19).

Taxonomic summary. Holotype male. BraziL, Rio de Janeiro: Mangaratiba, (Reserva Ecológica Rio das Pedras, $22^{\circ} 59^{\prime} 29.4^{\prime \prime}$ S, 4406'02.6”'W), 23.V.2009, J.L. Nessimian leg., light trap (DZRJ). Paratypes. Same data as holotype, 2 males, 2 
females (DZRJ); Rio de Janeiro: Angra dos Reis, (Rio Bracuí), 10.V.2002, J.L. Nessimian leg., light trap, 2 males (MZSP); Macaé, (Córrego Duas Barras, 22¹5'52.1”S, 4203'44.0”W, 217 m), 21.III.2009, B.H.L. Sampaio, G.A. Jardim, I.C. Gonçalves, V.P. Alecrim \& J.L. Nessimian leg., light trap, 1 male (DZRJ).

Etymology. The species name refers to the State of Rio de Janeiro. In Brazil, a native from this state is usually referred to as fluminense, from the Latin word flumen (stream or river).

Remarks. The new species is placed in the simplex group based on the simple antennae and absence of a costal bulla on the forewing. Costatrichia fluminensis sp. nov. can be easily distinguished from C. simplex by the male genitalia. The new species has the segment IX bearing a pair of long, slender downturned processes on the posterior margin (Fig. 14) and the phallus has a dorsal spatulate process and a ventral spinelike process on the apex, but no basal loop (Figs 15 and 16). This species is described from the Atlantic Forest of southern and northern Rio de Janeiro.

\section{ACKNOWLEDGEMENTS}

We thank Gabriel Mejdalani (MN-UFRJ) and two anonymous reviewers for useful comments that improved this paper. We are grateful to Brunno H.L. Sampaio, Gabriela A. Jardim, Inês C. Gonçalves, Nelson Ferreira Jr, and Viviani P. Alecrim (IB-UFRJ) for assistance in collecting material. We thank especially G.A. Jardim for donating specimens from her M.Sc. dissertation. Vale Company and the Laboratório de Limnologia (UFRJ) provided assistance in collecting trips at FLONA de Carajás and at APA do Igarapé Gelado. We also thank the Instituto Brasileiro do Meio Ambiente e dos Recursos Naturais Renováveis (IBAMA) for issuing collecting permits and Clubmed
Brasil for allowing our access to Reserva Ecológica Rio das Pedras. The Conselho Nacional de Desenvolvimento Científico e Tecnológico (CNPq) partially supported this study (Process 47.2666/2007-0). The Coordenação de Aperfeiçoamento de Pessoal de Nível Superior (CAPES) and CNPq provided fellowships to APMS and JLN, respectively.

\section{LITERATURE CITED}

FLINT JR, O.S. 1970. Studies of Neotropical caddisflies, X: Leucotrichia and related genera from North and Central America (Trichoptera: Hydroptilidae). Smithsonian Contributions to Zoology 60: 1-64.

FLINT JR, O.S. 1992. Studies of Neotropical caddisflies, XXXVIII: A review of the classification and biology of the Neotropical microcaddisflies, with description of a new genus (Trichoptera: Hydroptilidae: Leucotrichiini), p. 525-531. In: D. Quintero \& A. Aiello (Eds). Insects of Panama and Mesoamerica. New York, Oxford University Press.

Flint JR, O.S.; R.W. Holzenthal \& S.C. Harris. 1999. Catalog of the Neotropical Caddisflies (Insecta: Trichoptera). Columbus, Ohio Biological Survey, IV+239p.

Holzenthal, R.W. \& S.C. Harris. 1999. The genus Costatrichia Mosely in Costa Rica, with a review of the Neotropical species (Trichoptera: Hydroptilidae). Proceedings of the Entomological Society of Washington 101 (3): 540-568.

Marshall, J.E. 1979. A review of the genera of the Hydroptilidae (Trichoptera). Bulletin of the British Museum (Natural History), Entomology Series 39 (3): 135-239.

Mosely, M.E. 1937. Mexican Hydroptilidae (Trichoptera). Transactions of the Royal Entomological Society of London 86: 151-190.

Submitted: 02.III.2010; Accepted: 16.IX.2010.

Editorial responsibility: Gabriel L.F. Mejdalani

ZOOLOGIA 27 (5): 837-843, October, 2010 